\title{
Facial symmetry evaluation after experimentally displaced condylar process fracture in methotrexate treated rats ${ }^{1}$
}

\author{
Avaliação da simetria facial após fratura experimental com desvio do processo condilar em \\ ratos tratados com metotrexato
}

\begin{abstract}
Samantha Cristine Santos Xisto Braga Cavalcanti', Luciana Corrêa ${ }^{\text {II }}$, João Gualberto de Cerqueira Luz ${ }^{\text {III }}$
'DDS, Fellow Master degree, Postgraduate Program, Department of Oral and Maxillofacial Surgery, School of Dentistry, USP, Sao Paulo-SP, Brazil. Conception and outlining of the study and responsible for intellectual and scientific containts of the article, acquisition and interpretation of data, statistical analysis, manuscript writing, resource captivation.

IIDDS, PhD, Assistant Professor, Department of Stomatology, Division of General Pathology, School of Dentistry, USP, Sao Paulo-SP, Brazil. Acquisition and interpretation of data, critical revision.

IIIDDS, PhD, Chairman, Department of Oral and Maxillofacial Surgery, Division of Maxillofacial Traumatology, School of Dentistry, USP, Sao PauloSP, Brazil. Manuscript writing, critical revision, responsible for English language, resource captivation.
\end{abstract}

\begin{abstract}
PURPOSE: To investigate the facial symmetry of high and low dose methotrexate (MTX) treated rats submitted to experimentally displaced mandibular condyle fracture through the recording of cephalometric measurements.

METHODS: One hundred male Wistar rats underwent surgery using an experimental model of right condylar fracture. Animals were divided into four groups: A - saline solution (1mL/week); B - dexamethasone (DEX) (0,15mg/Kg); C - MTX low dose (3 mg/Kg/ week); D - MTX high dose (30 mg/Kg). Animals were sacrificed at 1, 7, 15, 30 and 90 days postoperatively (n=5). Body weight was recorded. Specimens were submitted to axial radiographic incidence, and cephalometric mensurations were made using a computer system. Linear measurements of skull and mandible, as well as angular measurements of mandibular deviation were taken. Data were subjected to statistical analyses among the groups, periods of sacrifice and between the sides in each group ( $\alpha=0.05)$.

RESULTS: Animals regained body weight over time, except in group D. There was reduction in the mandibular length and also changes in the maxilla as well as progressive deviation in the mandible in relation to the skull basis in group D.

CONCLUSION: Treatment with high dose methotrexate had deleterious effect on facial symmetry of rats submitted to experimentally displaced condylar process fracture.
\end{abstract}

Key words: Surgery, Oral. Mandibular Condyle. Methotrexate. Temporomandibular Joint. Maxillary Fractures. Rats.

\section{RESUMO}

OBJETIVO: Avaliar a simetria facial de ratos tratados com metotrexato (MTX), em dose alta e baixa, submetidos à fratura experimental do processo condilar com desvio por meio de mensurações cefalométricas.

MÉTODOS: Cem ratos Wistar machos foram submetidos a procedimento cirúrgico utilizando modelo experimental de fratura de côndilo do lado direito. Os animais foram distribuídos em quatro grupos: A - soro fisiológico (1mL/semana); B - dexametasona (DEX) $(0,15 \mathrm{mg} / \mathrm{Kg})$; C - MTX baixa dose (3mg/Kg/semana); D - MTX alta dose (30mg/Kg). Os períodos de sacrifício foram de 1, 7, 15, 30 e 90 dias de pós-operatório $(n=5)$. O peso dos animais foi documentado. Foram realizadas mensurações lineares da maxila e da mandíbula, bem como angulares do desvio mandibular. Os dados foram submetidos a análises estatísticas entre os grupos, períodos de sacrifício e entre os lados em cada grupo $(\alpha=0,05)$.

RESULTADOS: Os animais recuperaram peso ao longo do tempo, exceto no grupo D. Houve redução no comprimento mandibular com alterações também na maxila e desvio progressivo da mandíbula em relação à base do crânio no grupo $\mathrm{D}$.

CONCLUSÃO: O tratamento com metotrexato em alta dose teve efeito deletério na simetria facial de ratos submetidos à fratura do processo condilar.

Descritores: Cirurgia Bucal. Côndilo Mandibular. Metotrexato. Articulação Temporomandibular. Fraturas Maxilares. Ratos. 


\section{Introduction}

Condylar process fractures are common ${ }^{1,2}$. A favourable prognosis has been reported when these fractures are treated by closed methods ${ }^{3}$. The ability of the ascending ramus to repair and remodel following trauma has been tested experimentally ${ }^{4,5}$. Callus formation, with simultaneous repositioning of the condyle, can lead to normal temporomandibular joints ${ }^{5,6}$. However, there is some concern regarding skeletal changes, represented by mandibular asymmetry ${ }^{7-9}$.

The experimental model of condylar fracture, unilateral and medially displaced, allows the histological study of healing of fracture and articular sites ${ }^{3,6}$, as well as allows cephalometric analyses of their effects on facial structures ${ }^{5,9}$. This model follows the most frequent form of mandibular condyle fracture ${ }^{1,2,10}$.

Since its introduction as an antifolate agent more than fifty years ago, Methotrexate (MTX) has been widely used drug in medical, surgical, dermatological and pediatric specialties. MTX and its active metabolites have made a significant impact on the treatment of a wide range of diseases such as neoplasms, rheumatoid arthritis and psoriasis as well as being used as immunosuppressive agents in organ transplantation ${ }^{11-18}$. The administered dose of the drug is the differential in a given treatment. High doses are recommended for oncologic treatment ${ }^{19,20}$, while therapy with low doses are recommended for treatment of chronic inflammatory diseases such as rheumatoid arthritis and psoriasis ${ }^{21,22}$.

The purpose of this study was to investigate the facial symmetry of high and low dose MTX treated rats submitted to experimentally displaced mandibular condyle fracture through the recording of cephalometric measurements.

\section{Methods}

The study animals (100) were 3-month-old Wistar rats, with a mean body weight of $339.8 \pm 47.8 \mathrm{~g}$. All animals were acclimatized for 1 week under standard laboratory conditions at a temperature of $25^{\circ} \mathrm{C}$ with a 12-hour light cycle. The rats had free access to tap water and an ordinary diet of rodent feed (Labina, Agribands Purina, Sao Paulo, Brazil), administered in powder form for 2 weeks postoperatively, and in regular form in the remaining period. The study was approved by the local committee on research ethics (Protocol 09/2009).

\section{Study design}

All drugs were administered intraperitoneally, according to the weight of the rats. They were divided into four groups of 25 animals. Group A: control, saline solution ( $1 \mathrm{~mL} /$ week), with the first dose administered two hours before surgery; Group B: DEX $(0,15 \mathrm{mg} / \mathrm{Kg})$ (Decadron ${ }^{\circledR}$, Prodome, Campinas, Brazil), single dose, immediately after surgery ${ }^{23}$; Group C: MTX low dose (3mg/ $\mathrm{Kg}$ - adjusted with normal saline solution to a volume of $1 \mathrm{~mL}$ ), weekly (Miantrex ${ }^{\circledR}$, Pfizer, Guarulhos, Brazil), with the first dose administered two hours before surgery ${ }^{21}$; Group D: MTX high dose (30 $\mathrm{mg} / \mathrm{Kg}$ - adjusted with normal saline solution to a volume of 1 $\mathrm{mL}$ ), single dose administered two hours before surgery ${ }^{24}$.

\section{Surgical procedure}

Each animal was pre-medicated with $80.000 \mathrm{IU} / \mathrm{kg}$ of benzatin penicillin (Benzetacil ${ }^{\circledR}$, Eurofarma, Sao Paulo, Brazil). General anesthesia was induced by an injection of $50 \mathrm{mg} / \mathrm{kg}$ of ketamine 10\% (Cetamin ${ }^{\circledR}$, Rhobifarma, Hortolandia, Brazil), and $0.8 \mathrm{mg} / \mathrm{kg}$ of xylazine $2 \%$ Xilazin $^{\circledR}$, Rhobifarma, Hortolandia, Brazil). A right side preauricular incision of $1 \mathrm{~cm}$ was made, followed by blunt dissection through the masseter muscle, just below the zygomatic arch, and exposure of the condylar process. Fracture was achieved by using a mosquito (Halstead) forceps, and the condylar fragment was deviated medially ${ }^{3}$. Care was taken so as not to damage the articular surfaces. The procedures were concluded by suturing in layers. Postoperative analgesia was induced by an injection of tramadol $0.3 \mathrm{mg} / \mathrm{Kg}\left(\right.$ Tramal $^{\circledR}$, Pfizer, Guarulhos, Brazil) after the surgical procedure. Animals were sacrificed by $\mathrm{CO}_{2}$ asphyxiation at 1, 7, 15, 30 and 90 days postoperatively $(n=5)$, their heads were removed and fixed in $10 \%$ buffered formalin. Body weight was recorded on the first day of the experiment and at death.

\section{Cephalometric evaluation}

Following formalin fixation for 1 week, radiographs in axial (dorso-ventral) projection of the skull were obtained, and care was taken to maintain the horizontal and vertical planes. Radiographs were taken with a standard dental machine at 56 $\mathrm{kV}$ and $10 \mathrm{~mA}$, with an exposure time of $0.4 \mathrm{~s}$. A constant $30 \mathrm{~cm}$ focus-to-film distance was maintained and periapical films were used (Kodak Ektaspeed Plus ${ }^{\circledR}$, Rochester, NY, USA). Radiographs were subjected to computerized cephalometric evaluation. The radiographic images were digitized, and measurements obtained with Imagelab ${ }^{\circledR}$ software (Softium Informatica, Sao Paulo, Brazil).

From the axial radiographs, the following distances were measured bilaterally, in mandibles: AP- II - angular process to lower insertion of incisor (the most anterior limit of the lower bone insertion of this tooth); AP-IP'- angular process to lower incisal point (the intersection of the lingual face of lower incisors with the 
midline) $)^{5}$; and in skull: TB-IF - tympanic bulla (the most anterior portion of this round, voluminous structure of the skull base) to infraorbital foramen (the vertex of the image of this foramen); and IF-IP - infraorbital foramen to upper incisal point (the intersection of the lingual face of upper incisors with the midline). Angular measurements were also registered. Angle $\alpha$ : deviation of the mandible, right angle with reference to a line between both tympanic bullae ${ }^{3}$; angle $\hat{A}$ : deviation of the mandible relative to the maxilla, formed between lines from the midpoint between both TB, one to IP and another to IP'9 (Figure 1).
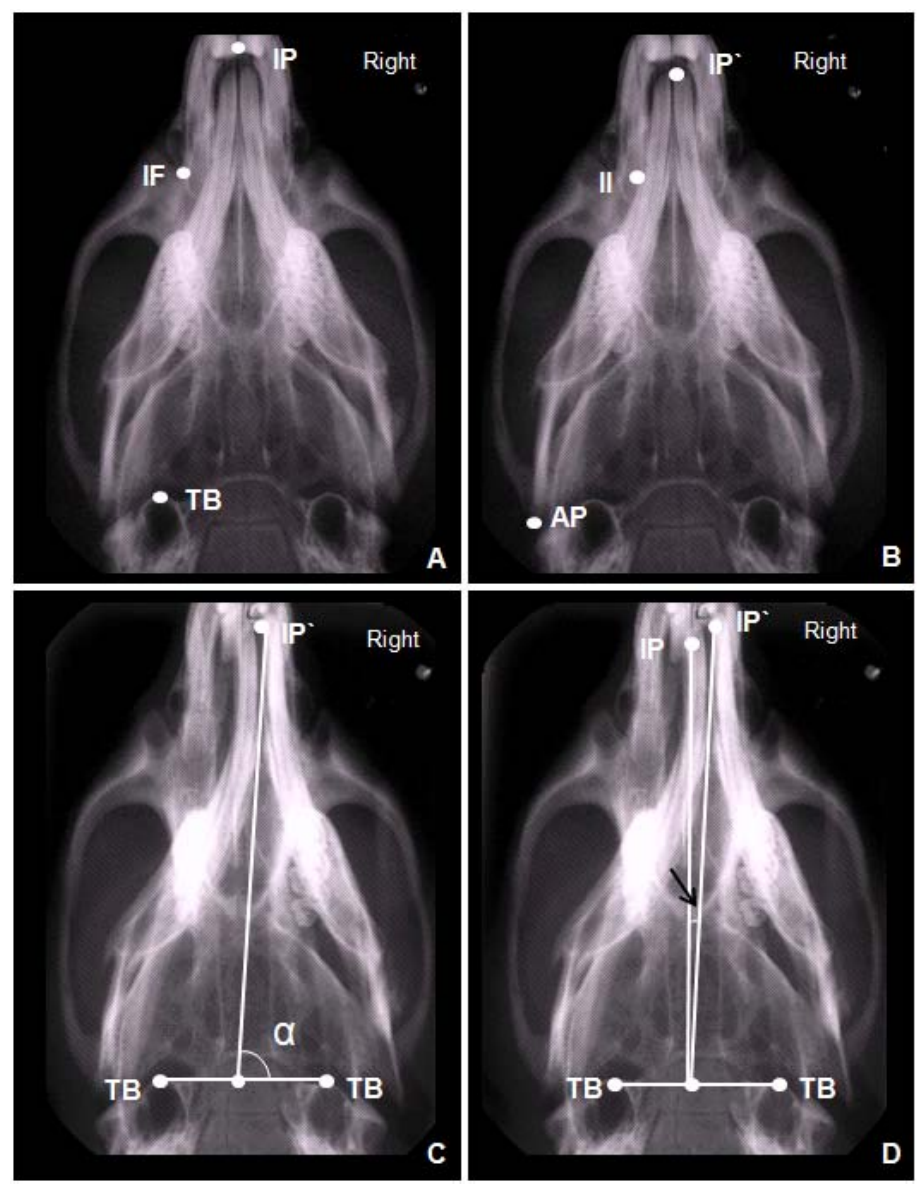

FIGURE 1 - Axial radiographs and cephalometric reference points. A. Skull; TB = tympanic bulla, IF = infraorbital foramen and IP = upper incisal point. B. Mandible; $\mathrm{AP}=$ angular process, $\mathrm{II}=$ insertion of incisor e IP $^{\prime}=$ lower incisal point. C. Measurement of angle $\alpha$. D. Arrow $=$ measurement of angle $\hat{A}$.

\section{Statistical analysis}

Results were analyzed using BioEstat 5.0 software (Sociedade Civil Mamiraua / MCT - CNPq, Belem, Brazil). The criterion of significance was a probability of 0.05 . Mean values of rate of gain or loss of body weight were obtained. A one-way analysis of variance (ANOVA) was performed to evaluate possible differences among the rate of gain or loss of body weight in the periods of sacrifice within the same group. Tukey's test was used to determine statistical significance between each period. Data obtained from the cephalometric evaluation were tested by oneand two-way ANOVA and Tukey's test. The paired Student's t-test was also used to compare the mean values from the right and left sides.

\section{Results}

\section{Macroscopic features}

After the surgical procedure, the animals continued with food and water intake. Signs of drug-related toxicity (piloerection and lethargy), diarrhea (soft feces) and mucositis were observed in animals undergoing chemotherapy with MTX high dose. The animals also continued to gain weight. The one-way ANOVA showed that there was a statistical difference in weight gain among the periods of sacrifice in control $(p<0.001)$, DEX $(p<0.001)$ and MTX low dose $(p<0.001)$ groups. There was no statistical difference in weight regain among the different periods of sacrifice in MTX high dose group $(p=0.249)$. Tukey's test showed the statistical differences between periods of sacrifice and is represented by different letters in Table 1 .

TABLE 1 - Mean values and standard deviations (SD) of the rate of gain or loss of weight ( $\mathrm{g}$ ) and significance of Tukey's test.

\begin{tabular}{|c|c|c|c|c|}
\hline \multirow[b]{2}{*}{ Period } & \multicolumn{4}{|c|}{ Groups } \\
\hline & $\begin{array}{c}\text { Control } \\
\text { Mean } \pm \text { SD }\end{array}$ & $\begin{array}{c}\text { DEX } \\
\text { Mean } \pm \text { SD }\end{array}$ & $\begin{array}{c}\text { MTX low dose } \\
\text { Mean } \pm \text { SD }\end{array}$ & $\begin{array}{c}\text { MTX high } \\
\text { dose } \\
\text { Mean } \pm \text { SD }\end{array}$ \\
\hline 1 day & $-11.4 \pm 11.0 \quad \mathbf{B}$ & $-27.8 \pm 3.0 \mathrm{C}$ & $-8.4 \pm 10.2$ B & $-21.4 \pm 8.8$ \\
\hline 7 days & $-12 \pm 67.5$ B & $29.6 \pm 20.6 \mathbf{~ F}$ & $-8.8 \pm 15.9$ B & $-47.4 \pm 19.8$ \\
\hline 15 days & $26.6 \pm 9.5$ B & $15 \pm 17.8 \mathbf{B}$ & $16 \pm 18.4 \mathbf{B}$ & $-33 \pm 70.7$ \\
\hline 30 days & $27.8 \pm 40.8$ B & $33.6 \pm 32.2 \mathrm{~F}$ & B $23.6 \pm 98.1 \mathbf{B}$ & $40.2 \pm 46.2$ \\
\hline 90 days & $139 \pm 73.4 \mathbf{A}$ & $174.8 \pm 20.0$ & A $161.6 \pm 40.9$ A & $37.4 \pm 144.7$ \\
\hline
\end{tabular}

Distinct letters mean statistical difference between periods.

Macroscopic examination of the specimens revealed facial asymmetry, with deviation of the mandible to the right (side of fracture), and asymmetric wear of the incisors. Some animals from MTX high dose group showed no incisal wear and the continuous tooth growth led to a large extraoral projection. 


\section{Cephalometric evaluation}

Mandible

Angular process to lower insertion of incisor (AP- II)

The paired Student's t-test showed that there was no significant difference between the right and left sides. On the left side one-way ANOVA showed that there was statistical difference among periods of sacrifice in Control and DEX $(p<0.010)$, with progressive growth according to Tukey's test, but not in MTX low dose $(p=0.087)$ and MTX high dose $(p=0.683)$ groups. On the right side there was also statistical difference among periods of sacrifice in Control and DEX $(p<0.013)$, with progressive growth according to Tukey's test, but not in MTX low dose $(p=0.508)$ and MTX high dose $(p=0.285)$ groups (Figure 2$)$. Two-way ANOVA showed that there was a statistical difference, on the left side, among the groups in the period of 7 days, but no significant difference in the periods of 1 day, 15, 30 and 90 days. Furthermore there was no significant difference among the groups on the right side.

\section{Angular process to lower incisal point $\left(A P-I P^{\prime}\right)$}

The paired Student's t-test showed that there was a significant difference between the right and left sides in group DEX, in the periods of $7(p=0.034)$ and $15(p=0.015)$ days and in MTX high dose group in the period of 7 days $(p=0.038)$. On the left side one-way ANOVA showed that there was a statistical difference among periods of sacrifice in all groups $(p<0.010)$, just as on the right side $(p<0.012)$, with progressive growth according to Tukey's test (Figure 2). Two-way ANOVA showed that there was a statistical difference, on the left side, among the groups in the periods of 7 and 15 days, but no significant difference in the periods of 1 day, 30 and 90 days, while on the right side there was a significant difference among groups in the periods of 7 and 15 days, and no significant difference in the periods of 1 day, 30 and 90 days.

Tukey's test showed that on the left side, to the AP-II, in the period of 7 days there was statistical difference between DEX and MTX high dose; to the AP-IP', in the period of 7 days there was statistical difference between DEX and MTX high dose, in the period of 15 days there was statistical difference between Control and MTX high dose and on the right side in the period of 7 days there was statistical difference between Control and DEX; DEX and MTX high dose and MTX low dose and MTX high dose; in the period of 15 days there was statistical difference between Control and MTX high dose.

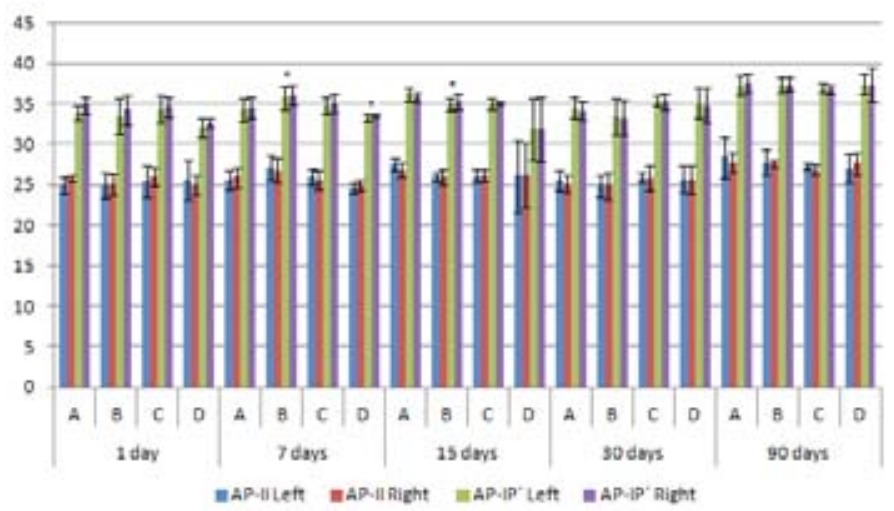

FIGURE 2 - Mean values and standard deviations (SD) of the cephalometric mensurations $(\mathrm{mm})$ of the mandible of all the groups according to the experimental period. $\mathrm{A}=\mathrm{Control}, \mathrm{B}=\mathrm{DEX}, \mathrm{C}=\mathrm{MTX}$ Low dose, D=MTX High dose. $(*)$ Statistical difference between right and left sides.

$\underline{\text { Skull }}$

Tympanic bulla to infraorbital foramen (TB-IF)

The paired Student's t-test showed that there was a significant difference between the right and left sides only in DEX group, in the period of 30 days $(p=0.042)$. On the left side oneway ANOVA showed that there was a statistical difference among periods of sacrifice in all groups $(p<0.005)$, with progressive growth according to Tukey's test, while on the right side there was a significant difference among periods in Control $(p<0.001)$, MTX low dose $(p=0.015)$ and MTX high dose $(p<0.001)$ groups, with progressive growth according to Tukey's test, and no significant difference in DEX $(p=0.355)$ group (Figure 3$)$. Two-way ANOVA showed that there was a statistical difference, on the left side, among the groups in the periods of 1 day, 7 and 15 days, but no significant difference in the periods of 30 and 90 days, and on the right side there was a significant difference among groups in the period of 1 day, but no significant difference in the periods of 7 , 15,30 and 90 days.

\section{Infraorbital foramen to upper incisal point (IF-IP)}

The paired Student's t-test showed that there was significant difference between the right and left sides only in Control group, in the period of 90 days ( $p=0.025$ ). On the left side one-way ANOVA showed that there was a statistical difference among periods of sacrifice in Control $(p=0.014)$ group, with progressive growth according to Tukey's test, and no significant difference in DEX $(p=0.190)$, MTX low dose $(p=0.337)$ and MTX high dose $(p=0.371)$ groups. On the right side there was a statistical difference between periods of sacrifice only in MTX 
high dose ( $p=0.013)$ group, with progressive growth according to Tukey's test, and no significant difference in Control $(p=0.527)$, $\operatorname{DEX}(p=0.129)$ and MTX low dose $(p=0.521)$ groups (Figure 3$)$. Two-way ANOVA showed that there was a statistical difference, on the left side, among the groups in the period of 15 days, and no significant difference in the periods of 1 day, 7, 30 and 90 days. On the right side there was a significant difference among groups in the periods of 15 and 90 days, but no significant difference in the periods of 1,7 and 30 days.

Tukey's test showed that on the left side, to the TB-IF, in the period of 1 day there was satatistical difference between Control and MTX low dose, Control and MTX high dose and MTX low dose and MTX high dose; in the periods of 7 and 15 days there was statistical difference between MTX high dose and the remaining groups; on the right side in the period of 1 day there was statistical difference between Control and MTX high dose and MTX low dose and MTX high dose; to the IF-IP, on the left and right sides in the period of 15 days there was statistical difference between Control and MTX high dose.

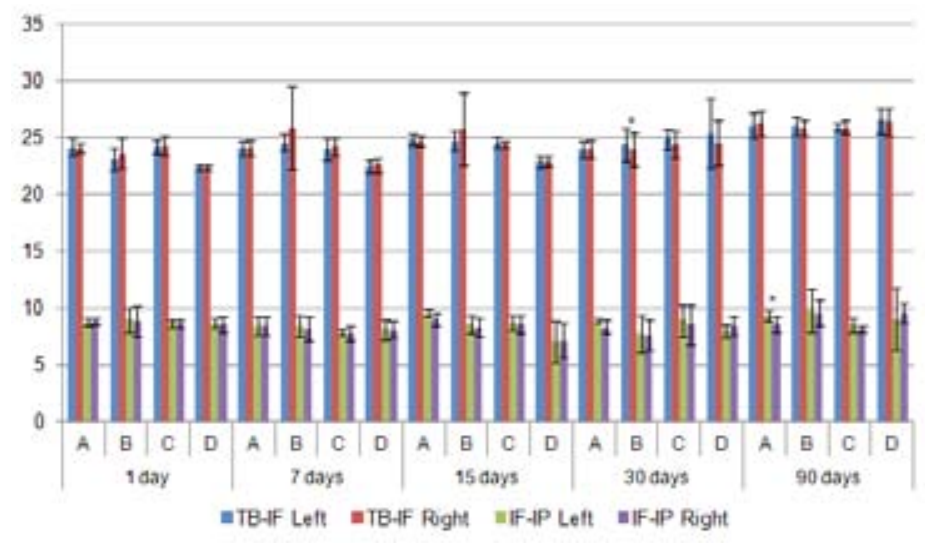

FIGURE 3 - Mean values and standard deviations (SD) of the cephalometric mensurations $(\mathrm{mm})$ of the skull of all the groups according to the experimental period. $\mathrm{A}=$ Control, $\mathrm{B}=\mathrm{DEX}, \mathrm{C}=\mathrm{MTX}$ Low dose, $\mathrm{D}=\mathrm{MTX}$ High dose. $\left({ }^{*}\right)$ Statistical difference between right and left sides.

\section{Angles $\alpha$ and $\hat{\mathrm{A}}$}

Mensuration of angle $\alpha$ revealed an increase in deviation over time in MTX high dose group. One-way ANOVA showed that there was a statistical difference among periods of sacrifice in MTX high dose $(p=0.010)$ group, and no significant difference in Control $(p=0.560), \operatorname{DEX}(p=0.923)$ and MTX low dose $(p=0.654)$ groups. Two-way ANOVA showed that there was not statistical difference among the groups $(p>0.050)$. One-way ANOVA showed that there was not statistical difference among the periods of sacrifice in the measurements of angle Â. Two-way ANOVA showed that there was a statistical difference among groups in the periods of 1 day $(p=0.015)$, and no significant difference in the periods of $7(p=0.784), 15(p=0.411), 30(p=0.523)$ and 90 $(p=0.313)$ days (Figure 4$)$.
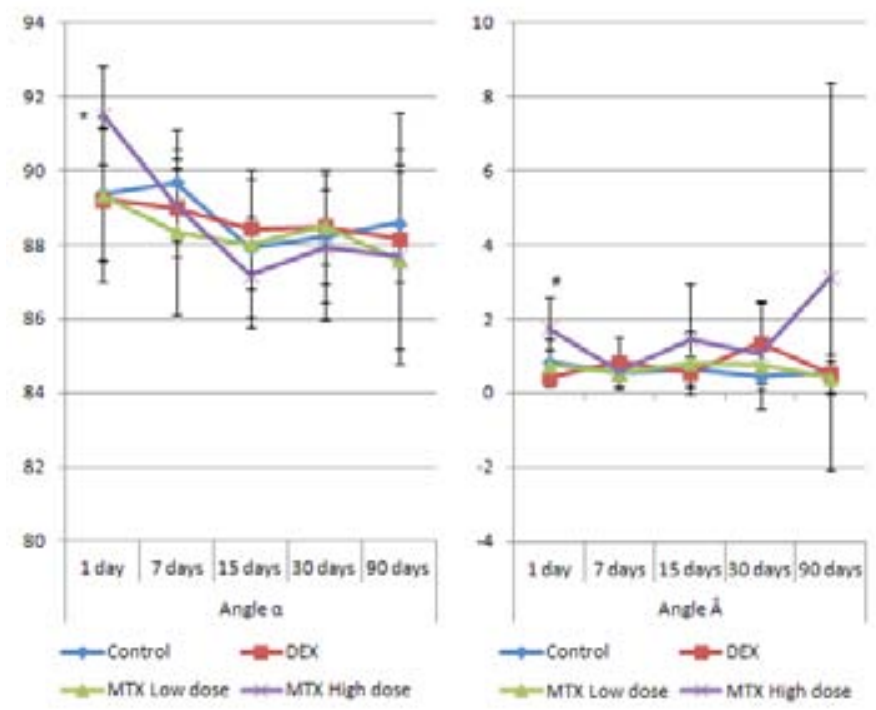

FIGURE 4 - Mean values and standard deviations (SD) of the cephalometric mensurations (degrees) of the angles $\alpha$ e Â of all the groups according to the experimental period. $(*)$ Statistical difference between periods in MTX High dose group. (*) Statistical difference between groups.

\section{Discussion}

When considering the use of MTX treatment for patients, it is important to know its effect on facial symmetry after experimentally displaced condylar process fracture. In this study mandibular condyle fractures were induced in high and low doses methotrexate (MTX) treated rats, and cephalometric mensurations focused on facial symmetry were taken. The final result was an asymmetry of the mandible, also with asymmetry of the maxilla in MTX high dose treated rats.

A series of published studies showed different doses of MTX and administration routes used in experimental models ${ }^{21}$, 23-27. An intraperitoneal administration route was selected since it is frequently used in animals and allows rapid absorption ${ }^{21,24,25}$. A comparative study evaluated serum levels of different concentrations of MTX and observed that a $3 \mathrm{mg} / \mathrm{Kg}$ dose gave serum levels similar to the levels attained in humans following a standard "rheumatoid arthritis dose" 21 . Another comparative study evaluated a single-dose injection of $30 \mathrm{mg} / \mathrm{Kg}$ of MTX in tumorbearing rats and observed that it exhibited antitumor activity ${ }^{24}$. In addition, a $0.15 \mathrm{mg} / \mathrm{kg}$ DEX dose in animals resembles anti- 
inflammatory treatment in humans ${ }^{23}$. It is difficult to directly compare these doses with those used clinically, because of the relatively elevated rat metabolism. The presence of a characteristic response to each drug suggests the need for further study to describe the effects of polychemotherapy ${ }^{24}$.

Our results show that after the surgical procedure, the animals continued with food and water intake. The treatment with high dose MTX showed signs of drug-related toxicity in animals as shown in a study that evaluated the impact of cancer chemotherapy on protein metabolism in healthy rats ${ }^{24}$. The animals also continued to gain weight but the cumulative body weight gain over the study was not significant in MTX high dose treated rats ${ }^{9,24}$.

An experimental model of condylar fracture, unilateral and medially displaced, which follows the most frequent form of mandibular condyle fracture and allows cephalometric evaluation, was used in this study ${ }^{6}$. Cephalometric evaluations from radiographs of specimens using a computer system, as in this study, lead to reliable measurements, reducing technical difficulties ${ }^{5,9,28}$. Distances found were similar to those noted in other experiments $^{5,28,29}$. In the cephalometric evaluation it was possible to measure linear distances, and also the mandibular deviation, by measuring the angles $\alpha$ and $\hat{\mathrm{A}}^{3,5,9,30,31}$. From an experimental model, only cautious conclusions can be drawn concerning human subjects. There are differences in the temporomandibular joint form and muscular system between rodents and omnivores ${ }^{5}$.

Cephalometric evaluations identified significant progressive growth of the animals. The distance angular process to lower insertion of incisor, in mandible, of DEX and MTX high dose groups, shared significant differences between the sides in the periods of seven and 15 days. The distance tympanic bulla to infraorbital foramen, in maxilla, of DEX group also shared significant difference between the sides in the period of 30 days. The asymmetry between sides may be attributable to the drug treatment but there was probably a recovery over time because the only distance that showed significant difference between the sides in the period of 90 days was infraorbital foramen to upper incisal point, in maxilla, of Control group, and similar findings were reported before ${ }^{5}$.

Based on the results of the severe mandibular shortening, as well as maxillary shortening on MTX High dose group, it can be seen that the consequences on facial symmetry after condylar fractures in MTX high dose treated rats were worse than the ones in DEX, MTX low dose treated and healthy rats. Facial asymmetry is a consequence of the unfavorable healing of condylar fractures ${ }^{3,5,32,33}$ and it is important to know the role of drug treatments in this outcome. Studies are being conducted in order to understand the effect of these drugs on the healing of condylar fractures.

Measurements of angle $\alpha$ were used to evaluate the mandibular deviation, with reference to the base of the skull, while angle $\hat{A}$ measurements were used to evaluate the deviation of the median line of the mandible in relation to the maxillary median line. There was a tendency towards deviation of the mandible to the fracture side 9 . However, there was significance only in MTX high dose group, indicating negative effects on the fracture repair. Some animals from MTX high dose group showed no incisal wear, and the continuous tooth growth led to a large extraoral projection which may have contributed to the progressive mandibular deviation found. Thus, the effects of the condylar fracture were significant in the MTX high dose group, demonstrated by asymmetry of the maxilla and mandible, especially in the final period of the experiment. The fact that the results of angle Â have not followed angle $\alpha$ can be explained by a possible maxillary growth influencing mandibular growth and vice versa by occlusal intercuspation ${ }^{5,9,34}$.

\section{Conclusion}

The treatment with high dose methotrexate had a deleterious effect on facial symmetry of rats submitted to experimentally displaced condylar process fracture.

\section{References}

1. Silvennoinen U, lizuka T, Lindqvist C, Oikarinen K. Different patterns of condylar fractures: an analysis of 382 patients in a 3-year period. J Oral Maxillofac Surg. 1992;50:1032-7.

2. Joss U, Kleinheinz J. Therapy of condylar neck fractures. Int J Oral Maxillofac Surg. 1998;27:247-54.

3. Luz JG, Araújo VC. Rotated subcondylar process fracture in the growing animal: an experimental study in rats. Int J Oral Maxillofac Surg. 2001;30:545-9.

4. Yücel E, Börkan Ü, Mollaoglu N, Erkmen E, Günhan Ö. Histological evaluation of changes in the temporomandibular joint after direct and indirect trauma: an experimental study. Dent Traumatol. 2002; 18:212-6.

5. Teixeira VCB, Teixeira ACB, Luz JGC. Skeletal changes after experimentally displaced condylar process fracture in growing rats. J Craniomaxillofac Surg. 2006;34:220-5.

6. Teixeira AC, Luz JGC, Araújo VC, Araújo NS. Healing of the displaced condylar process fracture: an experimental study. J Cranio Maxillofac Surg. 1998;26:326-30.

7. Hovinga J, Boering G, Stegenga B. Long term results of nonsurgical management of condylar fractures in children. Int J Oral Maxillofac Surg. 1999;28:429-40.

8. Strobl H, Emshoff R, Röthler G. Conservative treatment of unilateral condylar fractures in children: a long-term clinical and radiologic follow-up of 55 patients. Int J Oral Maxillofac Surg. 1999;28:95-8. 
9. Rodrigues L, Corrêa L, Luz JGC. Effects of the condylar process fracture on facial symmetry in rats submitted to protein undernutrition. Acta Cir Bras. 2011;26:88-93.

10. Oji C. Fractures of the facial skeleton in children: a survey of patients under the age of 11 years. J Cranio Maxillofac Surg. 1998;26:322-5.

11. Ros S, Juanola X, Condom E, Canas C, Riera J, Guardiola J, Del Blanco J, Rebasa P, Valverde J, Roig-Escofet D. Light and electron microscopic analysis of liver biopsy samples from rheumatoid arthritis patients receiving long-term methotrexate therapy. Scand. J Rheumatol. 2002;31:330-6.

12. Abrey L, Moskowitz C, Mason W, Crump M, Stewart D, Forsyth P, Paleologos N, Correa D, Anderson N, Caron D, Zelenetz A, Nimer $\mathrm{S}$. De Angelis L. Intensive methotrexate and cytarabine followed by high-dose chemotherapy with autologous stem-cell rescue in patients with newly diagnosed primary CNS lymphoma: an intentto-treat analysis. J Clin. Oncol. 2003;21:4151-6.

13. Schmiegelow K, Björk O, Glomstein A, Gustafsson G, Keiding N, Kristinsson J, Makipernaa A, Rosthj S, Szumlanski C, Sorensen T, Weinshilboum R. Intensification of mercaptopurine/methotrexate maintenance chemotherapy may increase the risk of relapse for some children with acute lymphoblastic leukemia. J Clin Oncol. 2003;21:1332-9

14. Weiss R, Woolf S, Demakos E, Holland E, Berry D, Falson G, Cirrincione T, Robbins A, Bothun S, Henderson I, Norton L. Natural history of more than 20 years of node-positive primary breast carcinoma treated with cyclophosphamide, methotrexate, and fluorouracil-based adjuvant chemotherapy: a study by the cancer and leukemia group b. J Clin Oncol. 2003;21:1825-35.

15. Aithal G, Haugk B, Das S, Card T, Burt A. Record C. Monitoring methotrexate-induced hepatic fibrosis in patients with psoriasis: are serial liver biopsies justified? Aliment Pharmacol Ther. 2004;19:3919.

16. Kaplan M, Cheng S, Price L. Bonis P. A Randomized Controlled Trial of colchicine plus ursodiol versus methotrexate plus ursodiol in primary biliary cirrhosis: Ten-year results. Hepatology. 2004;39:915-23.

17. Matsui H, Suzuka K, Yamazawa K, Tanaka N, Mitsuhashi A, Seki K, Sekiya S. Relapse rate of patients with low-risk gestational trophoblastic tumor initially treated with single-agent chemotherapy. Gynecol Oncol. 2005;96:616-20.

18. Al-Ali SY, Hassan IM, Sadek S. Ultrastructural changes in rat livers perfused in vitro and in vivo with a high dose of methotrexate. Histol Histopathol. 2005;20:1131-45.

19. Delepine N, Delepine G, Bacci G, Rosen G, Desbois JC. Influence of methotrexate dose intensity on outcome of patients with high grade osteogenic osteosarcoma. Cancer. 1996;78:2127-35.

20. Jaffe N, Gorlick R. High-dose methotrexate in osteosarcoma let the questions surcease - Time for final acceptance. J Clin Oncol. 2008;26:4365-6.

21. May KP, West GS, Mcdermott MT, Huffer WE. The effect of lowdose methotrexate on bone metabolism and histomorphometry in rats. Arthritis Rheum. 1994;37:201-6.

22. Warren RB, Chalmers RJ, Griffiths CE, Menter A. Methotrexate for psoriasis in the era of biological therapy. Clin Exp Dermatol. 2008;33:551-4.

23. Novaes GS, Mello SBV, Laurindo IMM, Cossermelli W. Low dose methotrexate decreases intraarticular prostaglandin and interleukin 1 levels in antigen induced arthritis in rabbits. J Rheumatol. 1996;23:2092-7.

24. Le Bricon T, Gugins S, Cynober L, Baracos VE. Negative impact of cancer chemotherapy on protein metabolism in healthy and tumorbearing rats. Metabolism. 1995;44:1340-8.

25. Alves AP, Pessoa CDOO, Costa-Lotufo 1, Moraes Filho MO.
Radiographic and histological evaluation of bisphosphonate alendronate and methotrexate effects on rat mandibles inoculated with Walker 256 carcinosarcoma. Acta Cir Bras. 2007;22:457-64.

26. Fuskevåg OM, Kristiansen C, Lindal S, Aarbakke J. Maximum tolerated doses of methotrexate and 7-hidroxy-methotrexate in a model of acute toxicity in rats. Cancer Chemother Pharmacol. 2000;46:69-73.

27. Laurindo IMM, Mendes FL, Novaes GS, Mello SBV, Falco V, Jorgetti V. Methotrexate inhibition of bone mineral density increase in growing rabbits: Prevention by folinic acid. Clin Exp Rheumatol. 2003;21(5):581-6.

28. Del Campo AI, Elizondo MM, Magnelli LM, Valadez ASOntiveros DS. Craniofacial development in rats with early resection of the zygomatic arch. Plast Reconstr Surg. 1995;95:486-95.

29. Cruz DZ, Rodrigues L, JGC Luz. Effects of detachment and repositioning of the medial pterygoid muscle on the growth of the maxilla and mandible of young rats. Acta Cir Bras. 2009;24:93-7.

30. Yamamoto MK, Novelli MD, Luz JGC. Effects of unilateral upper incisor extraction on facial growth of young rats. J Nihon Univ Sch Dent. 1997;39(4):191-5.

31. Li Z, Zhang W, Li Z-B. The role of the disc in the healing of displaced subcondylar fracture in the growing period: an experimental study in rats. Int J Oral Maxillofac Surg. 2010;39:388-93.

32. Proffit WR, Vig KWL, Turvey TA. Early fracture of the mandibular condyles: frequently an unsuspected cause of growth disturbances. Am J Orthod. 1980,78:1-24.

33. Takatsuka S, Terai K, Yoshida K, Narinobou M, Ueki K, Nakagawa $\mathrm{K}$, Yamamoto E. A comparative study of unilateral dislocated mandibular condyle fractures in the rabbit. J Craniomaxillofac Surg. 2005:33:180-7.

34. Altonen M, Ranta R, Ylipaavalniemi P. Midface deviation due to mandibular fractures. An experimental study clinical comparison. J Maxillofac Surg. 1978;6:143-7.

\section{Correspondence:}

João Gualberto de Cerqueira Luz.

Departamento Cirurgia, Prótese e Traumatologia Buco Maxilo

Faciais

Faculdade de Odontologia - USP

Avenida Professor Lineu Prestes, 2227

5508-900 São Paulo - SP Brasil

Tel.: (55 11)3091-7887

jgcluz@usp.br

Received: October 10, 2011

Review: December 12, 2011

Accepted: January 11, 2012

Conflict of interest: none

Financial source: CAPES and FAPESP

${ }^{1}$ Research performed at Experimental Laboratory, Department of Maxillofacial Surgery, Prosthetics and Traumatology, School of Dentistry, University of Sao Paulo (USP), Brazil. Part of dissertation. Tutor: Prof. Dr. João Gualberto de Cerqueira Luz. 